\title{
Expression of acid-stable proteins and modified lipopolysaccharide of Yersinia pestis in acidic growth medium
}

\author{
V. A. FEODOROVA and Z. L. DEVDARIANI \\ Laboratory of Hybridomas, Russia State Antiplague Research Institute 'Microbe', Saratov, Russia
}

\begin{abstract}
Growth medium simulating the phagolysosomal environment in which Yersinia pestis resides during its intracellular growth in vivo was made by acidification of $\mathrm{Ca}^{2+}$-deficient medium. When used for cultivation of $Y$. pestis $\mathrm{EV}-76\left(\mathrm{pLCR}^{+} ; \mathrm{pPst}^{+}\right.$;pFra $\left.{ }^{+}\right)$and its isogenic derivatives - KM-217 $\left(\mathrm{pLCR}^{+}\right.$;pPst ${ }^{-}$;pFra $\left.{ }^{-}\right)$and $\mathrm{KM}-218$ (pLCR $^{-}$;Ppst ${ }^{-}$; pFra $^{-}$) - this medium permitted survival and proliferation of viable bacteria without any growth restriction. Moreover, a correlation between the $\mathrm{pH}$ of growth medium and bacterial yield was established. Acidification completely inhibited fibrinolytic (pla protease) activity (PAA) of $Y$. pestis carrying pPst and allowed synthesis of specific outer-membrane proteins (Yops) without any degradation by the pla protease. Comparison of whole-cell lysates of the strains tested in PAAG-SDS showed that, in addition to previously described Yops, Y. pestis synthesised new acidic proteins which appeared only under acidic conditions and were encoded by pLCR or chromosomally. Some changes in O-specific polysaccharide chains of $Y$. pestis LPS that were dependent on cultivation temperature and $\mathrm{pH}$ of the medium were also demonstrated.
\end{abstract}

\section{Introduction}

Yersinia pestis is now considered to be a facultative intracellular parasite of the mammalian reticulo-endothelial system [1-5]. It is capable of survival and growth within macrophages in vivo and in vitro, residing within phagolysosomes [1-3]. To prevent phagocytosis, bacteria produce a set of specific outermembrane proteins (Yops) encoded by a 40-50-MDa plasmid (pLCR) common to the three Yersinia spp. that are pathogenic for man [4-7]. In vitro, Yops are released by pLCR-bearing Yersinia strains at $37^{\circ} \mathrm{C}$ into $\mathrm{Ca}^{2+}$-deficient media in the presence of $20 \mathrm{mM} \mathrm{Mg}^{2+}$ and this is associated with growth cessation (i.e., growth restriction) $[4,7-12]$. These proteins can be defined easily in both $Y$. pseudotuberculosis and $Y$. enterocolitica. In contrast, it is difficult to detect them in $Y$. pestis as they are rapidly degraded by pla protease (plasminogen activator, fibrinolysin), a product of another $Y$. pestis plasmid (pPst) which is absent from other Yersinia spp. [4, 7, 8, 11-13].

This study reports the importance of acidification of the $\mathrm{Ca}^{2+}$-deficient medium routinely used for studying

Received 6 Feb. 2001; revised version accepted 7 June 2001. Corresponding author: Dr V. A. Feodorova (e-mail: microbe@san.ru).
Yops synthesis by $Y$. pestis. This medium imitates the phagolysosomal environment in which bacteria reside during their intracellular growth in vivo. Acidic conditions stimulate bacterial growth and synthesis of Yops and other products by $Y$. pestis and completely inhibit $Y$. pestis plasminogen activator/fibrinolytic activity. Some of the proteins are related by mol. wt to the Yops and YPPs described previously [14] and others may be potential new members of the LCR family or are encoded chromosomally. Many of them are $\mathrm{pH}$-dependent.

\section{Materials and methods \\ Bacterial strains and bacterial cultivation}

The characteristics of $Y$. pestis EV-76 and its isogenic strains are listed in Table 1.

Table 1. Y. pestis EV-76 and its isogenic strains used in this study

\begin{tabular}{llc}
\hline Strain & Plasmid profile & Reference no. \\
\hline EV-76 & $\mathrm{pPst}^{+} ; \mathrm{pLCR}^{+} ; \mathrm{pFra}^{+}$ & 13 \\
$\mathrm{KM}-217$ & $\mathrm{pPst}^{-} ; \mathrm{pLCR}^{+} ; \mathrm{pFra}^{-}$ & 13 \\
$\mathrm{KM}-218$ & $\mathrm{pPst}^{-} ; \mathrm{pLCR}^{-} ; \mathrm{pFra}^{-}$ & 13 \\
\hline
\end{tabular}


The strains were grown in Hottinger broth at $\mathrm{pH} 7.2$, 7.0, 6.0, 5.0 and 4.0, containing $\mathrm{MgSO}_{4} 80 \mathrm{mg} / \mathrm{L}$ and galactose $0.1 \%$ for $24 \mathrm{~h}$ at $28^{\circ} \mathrm{C}$ and then for $24 \mathrm{~h}$ at $37^{\circ} \mathrm{C}$ or for $48 \mathrm{~h}$ at $28^{\circ} \mathrm{C}$. The strains grown in Hottinger broth, $\mathrm{pH} 7.2,7.0,6.0,5.0$ and 4.0, without any supplements were used as controls.

After cultivation, the bacteria were harvested and washed twice with phosphate-buffered saline (PBS), $\mathrm{pH}$ 7.2. Viable cell yields were determined by turbidity measurements and by standard plating techniques. Viable cells were counted and, after killing with sodium merthiolate at a concentration of 1 in 10000 , were used for assays.

\section{Plasminogen activator activity testing}

Y. pestis plasminogen activator activity (PAA) was assayed as described by Beesley et al. [15].

\section{ELISA}

Indirect dot-ELISA was used for studying the ability of all $Y$. pestis strains to synthesise Pla and YPPs encoded by $\mathrm{pLCR}$. Briefly, several drops of bacterial suspension were placed on to nitrocellulose membranes (NCMs), pore size $22 \mu \mathrm{m}$ (Schleicher-Schuell), and fixed at $110^{\circ} \mathrm{C}$ for $10 \mathrm{~min}$. After washing three times in PBS and blocking with skimmed milk $3 \%$ for $15 \mathrm{~min}$, the NCMs were incubated for $15 \mathrm{~min}$ with monoclonal antibodies (MAbs) to Pla [16] or rabbit polyclonal antibodies to YPPs [14], respectively. Peroxidaselabelled anti-mouse or anti-rabbit IgG (Gamaleya Institute, Russia) were employed as conjugates. $O$ Dianisidine (Sigma) was used as a substrate. Finally, the NCMs were dried and observed for colour differentiation.

\section{$S D S-P A G E$}

Whole-cell lysates of the tested strains grown as described above were subjected to SDS-PAGE according to Laemmli [17] with a stacking 4\% gel and separating $12.5 \%$ gel. Electrophoresis was done at $35 \mathrm{~mA}$ constant current in $25-192 \mathrm{mM}$ Tris-glycine (pH 8.3) plus SDS $0.1 \%$ buffer for c. $2.5 \mathrm{~h}$. A set of low-mol. wt markers (Sigma) was used. Gels were counterstained with Coomassie Brilliant Blue R 250 (Sigma) $0.2 \% \mathrm{w} / \mathrm{v}$ in ethanol $25 \% \mathrm{v} / \mathrm{v}$, acetic acid $7 \%$ $\mathrm{v} / \mathrm{v}$. For some experiments, proteinase K (PK)-treated whole-cell lysates of $Y$. pestis EV-76 grown at $28^{\circ} \mathrm{C}$ or $37^{\circ} \mathrm{C}$ were electrophoresed in the same conditions and gels were stained with silver according to Tsai and Frasch [18].

\section{Results}

\section{$Y$. pestis EV-76 plasminogen activator activity}

$Y$. pestis EV-76 grown at $37^{\circ} \mathrm{C}$ in a medium with neutral or slightly acidic $\mathrm{pH}$ expressed PAA, whereas the same strain grown in a medium with lower $\mathrm{pH}$ did not have this activity (Table 2). Y. pestis EV-76 grown at $28^{\circ} \mathrm{C}$ did not possess PAA independently of $\mathrm{pH}$.

In dot-ELISA, MAb to Fib gave a strong positive reaction with $Y$. pestis EV-76 grown in media in the $\mathrm{pH}$ range 7.2-6.0. No reaction with $Y$. pestis EV-76 grown in media with lower $\mathrm{pH}$ was observed (Table 2).

Table 2. Influence of different $\mathrm{pH}$ values on proliferative and plasminogen activator activities of $Y$. pestis strains in Hottinger broth

\begin{tabular}{|c|c|c|c|c|c|c|c|}
\hline $\begin{array}{l}Y . \text { pestis } \\
\text { strains }\end{array}$ & $\begin{array}{l}\text { Addition of } \\
20 \mathrm{mM} \mathrm{Mg}^{2+} \text { and } \\
\text { galactose } 0.1 \%\end{array}$ & Medium $\mathrm{pH}$ & $\begin{array}{l}\text { Cultivation } \\
\text { temperature } \\
\left({ }^{\circ} \mathrm{C}\right)\end{array}$ & $\begin{array}{c}\text { Viable cell } \\
\text { yield } \\
\left(n \times 10^{9}\right)\end{array}$ & $\begin{array}{l}\text { Multiplication } \\
\text { ratio* }\end{array}$ & $\begin{array}{l}\text { Plasminogen } \\
\text { activator } \\
\text { activity }\end{array}$ & $\begin{array}{l}\text { Reaction in dot- } \\
\text { ELISA with } \\
\text { MAb-Fib }\end{array}$ \\
\hline EV-76 & - & 7.2 & 28 & 25.0 & 1.00 & Clot & + \\
\hline EV-76 & + & 7.0 & 28 & 30.0 & 1.20 & Clot & + \\
\hline EV-76 & + & 6.0 & 28 & 45.5 & 1.82 & Clot & + \\
\hline EV-76 & + & 5.0 & 28 & 50.0 & 2.00 & Clot & + \\
\hline EV-76 & + & 4.0 & 28 & 90.0 & 3.60 & Clot & + \\
\hline EV-76 & - & 7.2 & 37 & 18.0 & 1.00 & No clot & + \\
\hline EV-76 & + & 7.0 & 37 & 25.5 & 1.41 & No clot & + \\
\hline EV-76 & + & 6.0 & 37 & 60.0 & 3.33 & No clot & + \\
\hline EV-76 & + & 5.0 & 37 & 87.5 & 4.86 & Clot & - \\
\hline EV-76 & + & 4.0 & 37 & 100.0 & 5.55 & Clot & - \\
\hline KM-218 & - & 7.2 & 37 & 18.1 & 1.00 & Clot & - \\
\hline KM-218 & + & 7.0 & 37 & 25.0 & 1.38 & Clot & - \\
\hline KM-218 & + & 6.0 & 37 & 77.0 & 4.25 & Clot & - \\
\hline KM-218 & + & 5.0 & 37 & 105.0 & 5.80 & Clot & - \\
\hline KM-218 & + & 4.0 & 37 & 105.0 & 5.80 & Clot & - \\
\hline KM-217 & - & 7.2 & 37 & 21.3 & 1.00 & Clot & - \\
\hline KM-217 & + & 7.0 & 37 & 84.7 & 3.97 & Clot & - \\
\hline KM-217 & + & 6.0 & 37 & 85.0 & 3.99 & Clot & - \\
\hline KM-217 & + & 5.0 & 37 & 83.3 & 3.91 & Clot & - \\
\hline KM-217 & + & 4.0 & 37 & 100.0 & 4.69 & Clot & - \\
\hline
\end{tabular}


Stimulatory effect of acidic $p H$ on growth of $Y$. pestis strains

As shown in Table 2, all $Y$. pestis strains grew well in the media containing $20 \mathrm{mM} \mathrm{Mg}^{2+}$ with no calcium at lower $\mathrm{pH}$ independently of plasmid composition and cultivation temperature. Moreover, the same phenomenon was found when strain EV-76 was grown in acidified Hottinger broth without any ion supplements. In all cases, bacterial growth was maximal in medium at $\mathrm{pH} 4.0$, and minimal in the same medium at $\mathrm{pH}$ $7.0-7.2$.

$p H$ and temperature effect on synthesis of $p L C R$ encoded proteins and other products by $Y$. pestis

Fig. 1 shows whole-cell lysate profiles of the strains grown in the presence of $20 \mathrm{mM} \mathrm{Mg}{ }^{2+}$ at $37^{\circ} \mathrm{C}$. More proteins were found in all the strains cultivated in media at $\mathrm{pH} 4.0$ than in the same strains cultivated in media at neutral or slightly acidic $\mathrm{pH}$ (about 7.0). Some of them (proteins 1-11 with mol. wts 38.0, 28.2, $26.3,23.9,22.4,20.9,19.5,16.9,15.1,12.6$ or $11.5 \mathrm{kDa}$, respectively) defined in both strain EV-76 and strain KM-217 were absent from strain KM-218. Thus, these proteins were plasmid-encoded (pLCR) polypeptides. Some proteins (nos 1, 2, 4) appeared to be resistant to degradation by pla protease, as they were detected in both strain EV-76 and strain KM-217 independently of $\mathrm{pH}$ (Figs. 1 and 2). Protein 3 was seen in strain EV-76 at every $\mathrm{pH}$ tested. In strain KM-217 it was visible only when the strain was grown in medium of $\mathrm{pH} 4.0-5.0$ (Fig. 1, lanes 1 and 2). Protein found in strain EV-76 independently of $\mathrm{pH}$ was seen more clearly if this strain was grown in medium at $\mathrm{pH} 5.0-$ 4.0.

Proteins 5-9 and 11 appeared in strain EV-76 grown only at $\mathrm{pH} 5.0-4.0$ and were absent when this strain was grown in routine conditions $(\mathrm{pH} 7.2-7.0)$, being completely degraded by the pla protease [4, 7, 10-14]. Some of these proteins (nos 5-7) were found in strain $\mathrm{KM}-217$ grown in medium at every $\mathrm{pH}(\mathrm{pH} 7.2-4.0)$. Protein 8 was seen in strain KM-217 grown in medium at $\mathrm{pH}$ 4.0. Both proteins 9 and 10 were seen in strain EV-76 at every $\mathrm{pH}$, while protein 10 (similar to protein 11) appeared in strain EV-76 at $\mathrm{pH} 4.0$ only when three times greater concentration of whole-cell lysate of this strain was used (Fig. 1, lane 6). Protein 11 was found in strain KM-217 only at $\mathrm{pH} 5.0-4.0$.

Interestingly, protein 12 with mol. wt $9.1 \mathrm{kDa}$ readily appeared only in strain EV-76 grown at $\mathrm{pH} 4.0$ and was absent from both strain KM-217 and strain KM-218. At the same time, all $Y$. pestis strains produced a protein with mol. wt similar to that of protein 12 , but as a minor band. Thus, protein 12 could be a product of pLCR, or any other $Y$. pestis plasmid, or the chromosome. In any case, protein 12 synthesis is $\mathrm{pH}$ dependent.

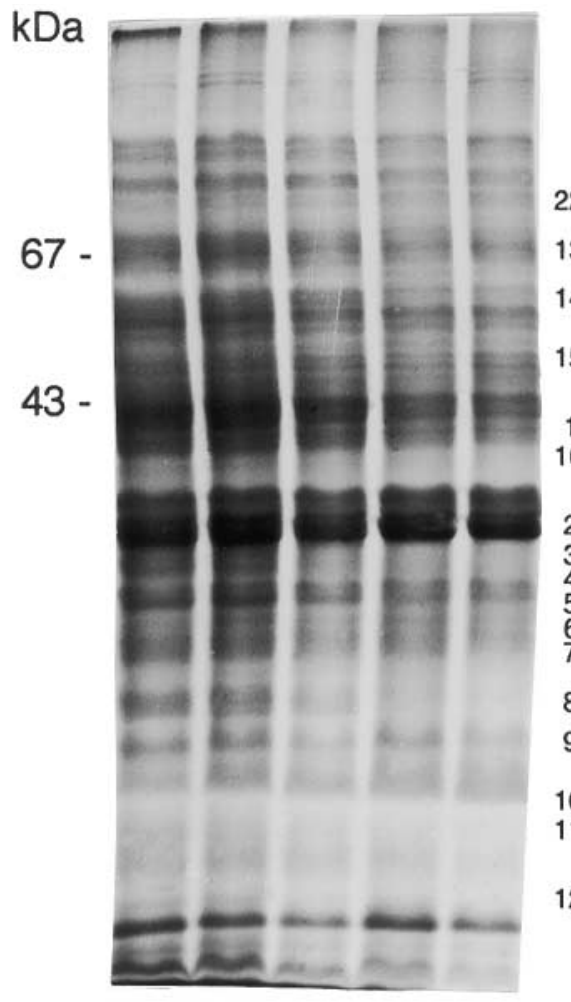

1

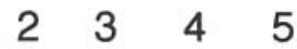

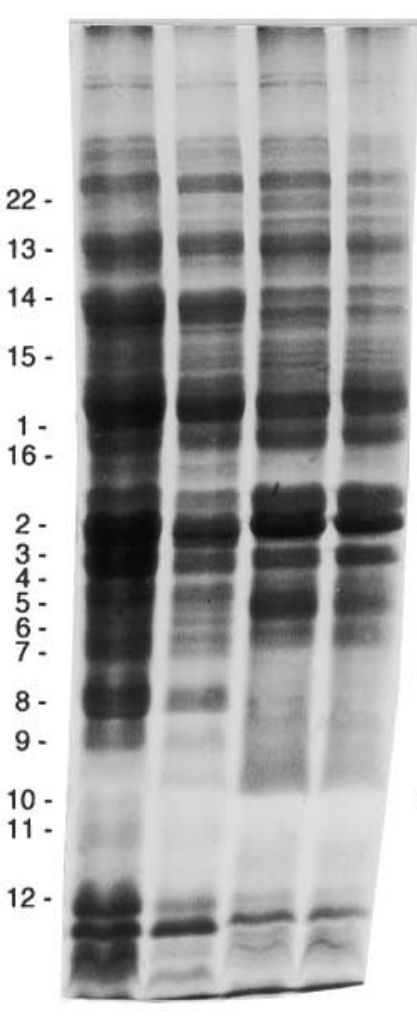

$\begin{array}{llll}6 & 7 & 8 & 9\end{array}$

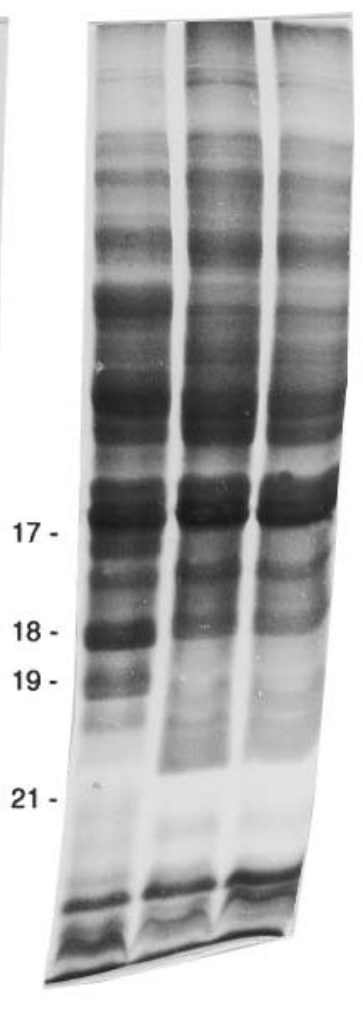

$\begin{array}{lll}10 & 11 & 12\end{array}$

Fig. 1. SDS-PAGE of whole-cell lysates of Y. pestis EV-76 (lanes 6-9), Y. pestis KM-217 (1-5) and Y. pestis KM-218 (10-12) grown at $37^{\circ} \mathrm{C}$ in the presence of $20 \mathrm{mM} \mathrm{Mg}^{2+}$, $\mathrm{pH} 7.2$ (lanes 5, 9, 12), $7.0(4,8,11), 6.0(3), 5.0(2,7)$ or 4.0 $(1,6,10)$. 


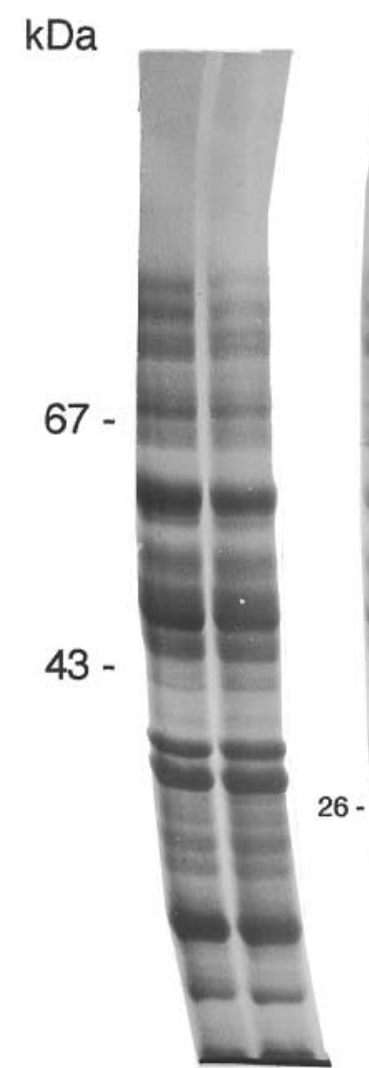

12

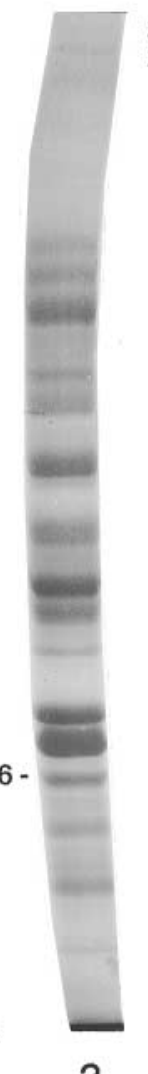

3

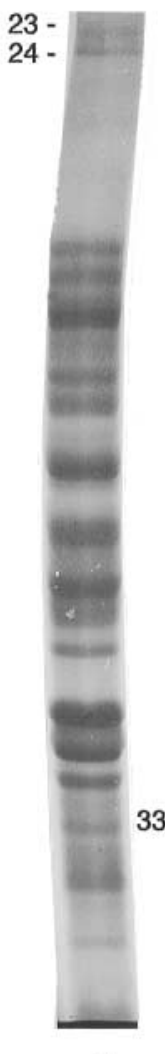

4

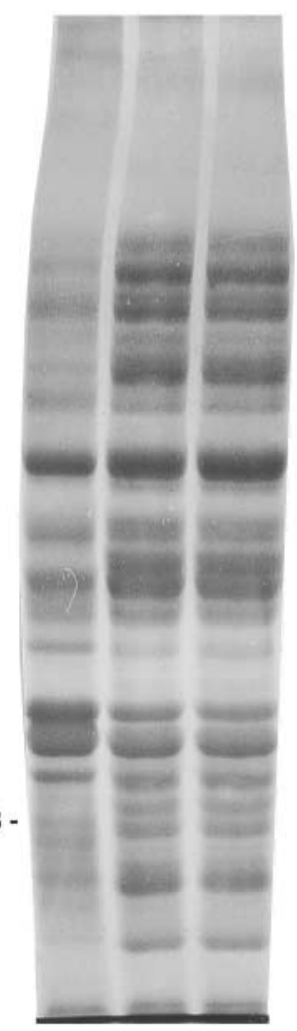

$\begin{array}{lll}5 & 6 & 7\end{array}$

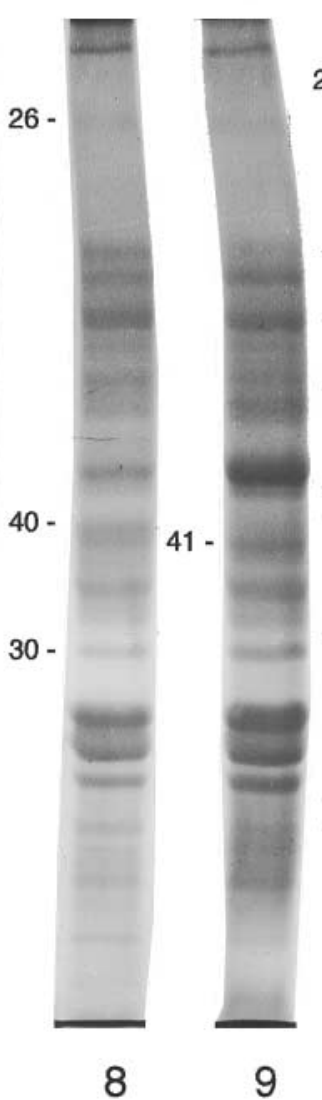

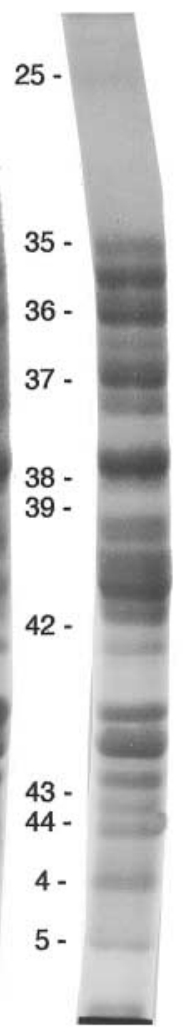

10

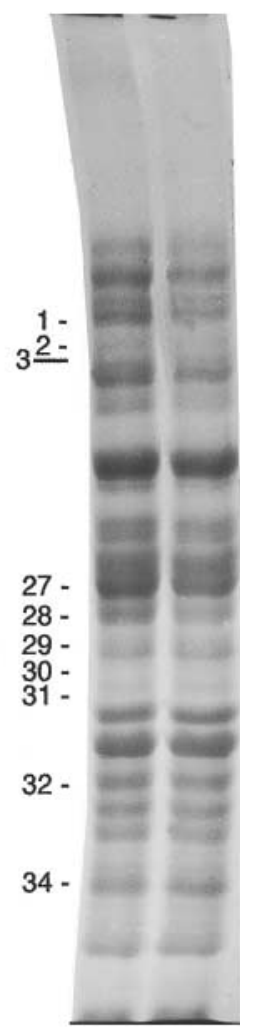

$11 \quad 12$

Fig. 2. SDS-PAGE of whole-cell lysates of $Y$. pestis EV-76 (lanes 3-12) or Y. pestis KM-218 (1, 2) grown at $28^{\circ} \mathrm{C}(\mathbf{3}-7)$ or at $37^{\circ} \mathrm{C}$ $(\mathbf{1}, \mathbf{2}, \mathbf{8}-\mathbf{1 2})$, pH $7.2(3,8), 7.0(4,9), 6.0(5,10), 5.0(1,6,11)$ or $4.0(2,7,12)$ in the presence of $20 \mathrm{mM} \mathrm{Mg}^{2+}$.

Proteins 13-16 with mol. wts 75.9, 63.1, 48.9 and $36.3 \mathrm{kDa}$, respectively, were found in $Y$. pestis strains independently of their plasmid composition. All these proteins were seen in strains EV-76, KM-217 and KM218 grown in medium at neutral $\mathrm{pH}(7.2,7.0,6.0)$ as minor bands, whereas they appeared in the same strains grown in acidic conditions ( $\mathrm{pH} 5.0-4.0)$ as major bands.

Proteins 17-21 with mol. wts 27.5, 21.9, 18.2, 15.9 and $12.1 \mathrm{kDa}$, respectively, were visualised only in strain KM-218 grown at $\mathrm{pH}$ 4.0. Thus, these proteins were chromosomally encoded polypeptides synthesised by $Y$. pestis only in acidic conditions. Interestingly, protein 22 with a mol. wt of $83.2 \mathrm{kDa}$, found in all $Y$. pestis strains as a major band at $\mathrm{pH} 7.0$ and as a minor band at $\mathrm{pH}$ 6.0-5.0, disappeared at $\mathrm{pH} 4.0$ in strains EV-76 and KM-218. Proteins 23, 24 and 26 with mol. wts $147.9,134.9$ and $121.0 \mathrm{kDa}$, respectively, had similar characteristics to protein 22 . These proteins also appeared in strain EV-76 grown in medium at a neutral or slightly acidic $\mathrm{pH}(7.2-6.0)$ and disappeared in acidic medium ( $\mathrm{pH} 5.0-4.0$ ) (Fig. 2). All these proteins (nos. 23, 24 and 26), as well as proteins 25, 30, 32 and 33 with mol. wts of $125.8,38.0,31.6$ and $28.2 \mathrm{kDa}$ respectively, were found in strain EV-76 but not in strain KM-218 independently of cultivation temperature. However, when strain EV-76 was grown at $37^{\circ} \mathrm{C}$, proteins 23-26 were present in larger amounts (these proteins were visualised as major bands whereas when strain EV-76 was grown at $28^{\circ} \mathrm{C}$ they appeared as minor bands). In contrast, protein 25 was seen only in acidic media at $\mathrm{pH}$ 5.0-4.0.

Protein 32 appeared in equally large amounts in strain EV-76 independently of cultivation temperature or $\mathrm{pH}$.

Protein 30 was seen only in acidic conditions ( $\mathrm{pH} 5.0-$ $4.0)$ in strain $\mathrm{EV}-76$ grown at $28^{\circ} \mathrm{C}$ or $37^{\circ} \mathrm{C}$.

Protein 33 was found in strain EV-76 grown at $28^{\circ} \mathrm{C}$ in medium at $\mathrm{pH}$ 6.0.

The remaining proteins (nos. 28, 29, 31, 34-44 with mol. wts of 43.6, 42.0, 37.0, 26.9, 95.5, 87.0, 70.8, $60.3,57.5,54.9,50.1,44.7,30.2,28.2 \mathrm{kDa}$, respectively) were identified in both strain EV-76 and strain KM-218. Some of them (proteins 28, 34-40, 42) were present in these strains independently of the $\mathrm{pH}$ of the medium while proteins 29, 31, 41, 43 and 44 appeared only in acidic conditions. Proteins 28, 31 and 35-44 were seen in strain EV-76 independently of cultivation temperature, whereas protein 29 appeared only when the strain was grown at $37^{\circ} \mathrm{C}$. At the same time, many proteins (nos. 28, 35, 37-40, 42 and, probably, no. 34) were degraded by the pla protease in strain EV-76 grown at $37^{\circ} \mathrm{C}$, as they were clearly visualised in acidic media ( $\mathrm{pH} 4.0-6.0)$. These proteins were seen as large diffuse zones in media with neutral and slightly acidic $\mathrm{pH}(\mathrm{pH}$ 6.0-7.2). 
LPS profiles of PK-treated $Y$. pestis EV-76 were not completely identical to each other. All possessed the predominant lower mol. wt component corresponding to the core lipid A region and several bands of intermediate mol. wt. However, their number was significantly less in the $Y$. pestis EV-76 grown at $\mathrm{pH} 4.0$ but not at $\mathrm{pH}$ 7.2. More changes in O-specific polysaccharide chains were seen in the strains grown without $\mathrm{Mg}^{2+}$ than in the same strains grown in the presence of $20 \mathrm{mM} \mathrm{Mg}^{2+}$. In the last case, Y. pestis EV-76 grown at $\mathrm{pH}$ 4.0-5.0 gave four bands of intermediate mol. wt and it appeared that the bacteria produced at least SRLPS with short or shortened O-side chains but not RLPS.

Most of the components found in $Y$. pestis EV-76 appeared in plasmidless $Y$. pestis KM-218. Thus, they were encoded by chromosomal genes. Interestingly, the additional higher mol. wt component was seen in $Y$. pestis EV-76 but not in $Y$. pestis KM-218. Thus, it was probably encoded by a plasmid.

More proteins were also seen in $Y$. pestis EV-76 grown in media without $\mathrm{Mg}^{2+}$, at $\mathrm{pH} 4.0$, than in the same strain cultured at $\mathrm{pH} 7.2$ independently of cultivation temperature (Fig. 3). These were 28.2-, 23.9-, 22.4-, 12.6-, 9.1-, 54.9- and 44.6-kDa proteins with mol. wts similar to proteins 2, 4, 5, 10, 12, 40 and 42, respectively. Proteins $45-57$ with mol. wts 83.2, 58.9,
$52.5,40.7,38.9,34.7,25.7,25.1,20.9,17.8,16.2,14.5$ and $9.3 \mathrm{kDa}$ were also seen.

\section{Discussion}

It has been shown previously that expression of $\mathrm{V}$ antigen and Yops by yersiniae in vitro is maximal at $37^{\circ} \mathrm{C}$ in media containing $20 \mathrm{mM} \mathrm{Mg}^{2+}$ with no $\mathrm{Ca}^{2+}$ and is associated with growth restriction [4, 7-12]. These conditions simulate the mammalian intracellular environment in which $Y$. pestis grows in its host target cell - the macrophage $[1-4,8]$. When residing within a phagolysomsome, bacteria are exposed to acidic hydrolases in acidic conditions (pH 3.5-4.0) [1, 19].

The present study modelled phagolysosomal conditions in vitro by acidification of a standard $\mathrm{Ca}^{2+}$-deficient medium and showed that acidic conditions stimulated $Y$. pestis proliferative activity with no growth restriction (Table 2). Therefore, the $Y$. pestis growth restriction in vitro described previously $[4,8,10]$ is obviously an artifact caused by an artificial growth environment not encountered in vivo $[4,10]$ when bacteria are residing within phagolysosomes [1-3]. The data obtained indicated that $Y$. pestis strains remained viable and proliferated in vitro in conditions imitating the phagolysosome environment in vivo.

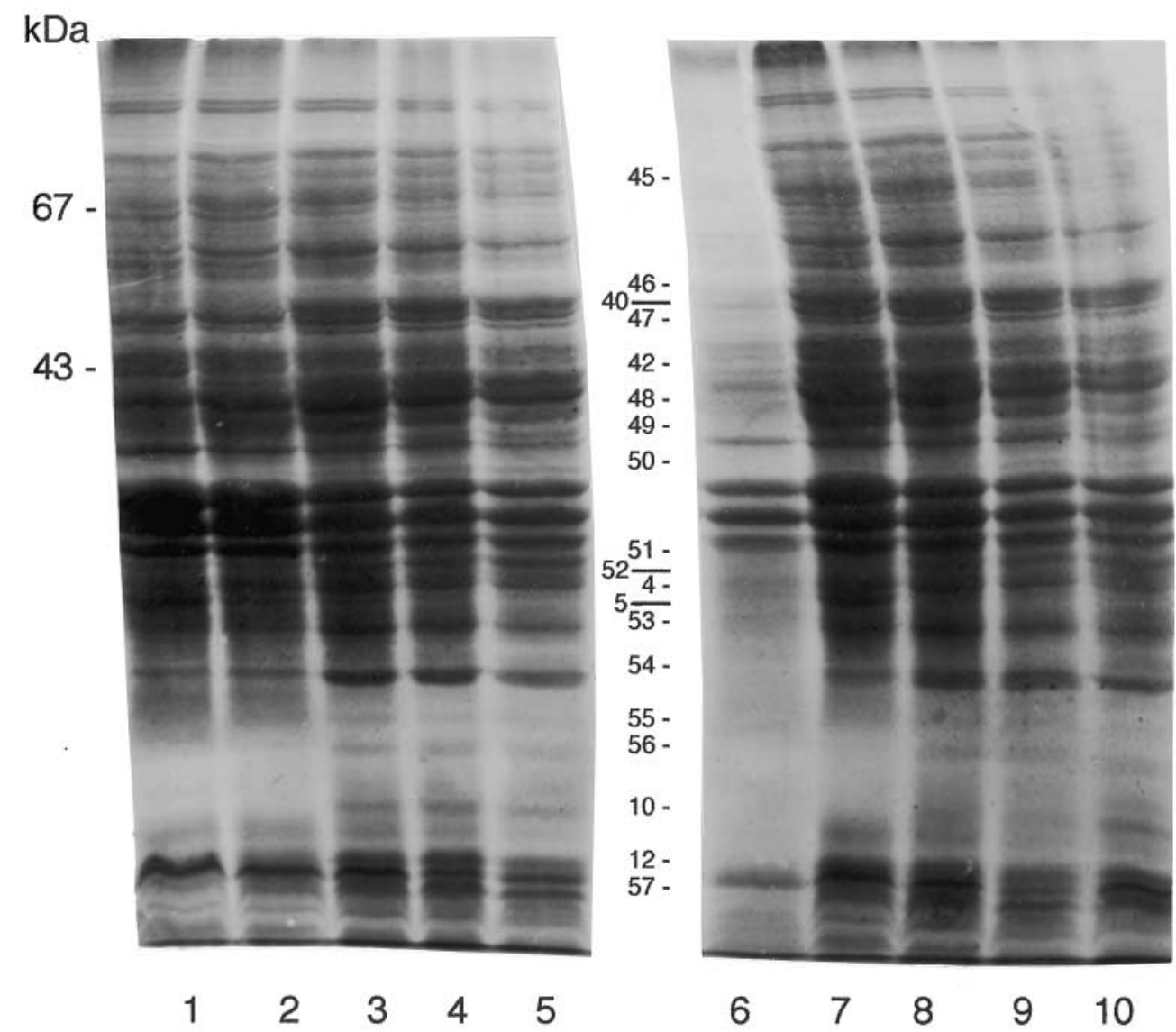

Fig. 3. SDS-PAGE of whole-cell lysates of $Y$. pestis EV-76 grown at $28^{\circ} \mathrm{C}$ (lanes 1-5) or at $37^{\circ} \mathrm{C}(\mathbf{6}-\mathbf{1 0})$, pH 7.2 (1, 6), $7.0(2,7)$, $6.0(3,8), 5.0(4,9)$ or $4.0(5,10)$ without any supplements. 
One fundamental question was whether Yops were really degraded by pla protease in the phagolysosomal environment as reported recently $[4,7,10-14]$ or whether Yops were synthesised and functioned in $Y$. pestis containing both $\mathrm{pLCR}$ and pPst. The latter supposition was highly probable because: (i) the pLCR permits bacterial survival and growth within phagolysosomes [1-3]; (ii) proteins encoded by this plasmid are released from $Y$. pestis only in the intracellular environment [4-6, 8, 10, 12, 14]; (iii) a significant role for these products in plague pathogenesis is clear [1$5,7-9,11,12,14]$; (iv) as an enzyme, pla protease as well as its precursor easily lost its proteolytic (fibrinolytic) activity at the acidic $\mathrm{pH}[20,21]$; (v) transformation of the precursor to pla (mature form, fibrinolysin) is possible only at neutral $\mathrm{pH}$ but not in acidic conditions [20,21]. Consequently, Y. pestis does not express PAA when residing within the phagolysosome. To confirm this hypothesis, PAA of Y. pestis EV76 grown at $37^{\circ} \mathrm{C}$ (when both Yops synthesis and PAA are maximal) was studied in media at $\mathrm{pH}$ 4.0-7.2. As expected, bacterial growth in acidic conditions produced complete inhibition of $Y$. pestis PAA (Table 2). This observation suggested that, in addition to pla (gene), Y. pestis possessed a special $\mathrm{pH}$-dependent regulatory mechanism or at least some regulatory gene(s) which blocked its PAA when bacteria resided within phagolysosomes. Moreover, these conditions could allow Yops synthesis and realisation of their functions without degradation by the pla protease. Thus, pla protease could not be responsible for specific degradation of Yops as reported previously [4, 7, 8, 10$14]$.

To provide additional evidence that no degradation of Yops occurs when bacteria remain in a phagolysosome, whole-cell lysates of $Y$. pestis EV-76 strain bearing all three 'canonical' plasmids (pLCR, pPst, pFra), KM-217 carrying only pLCR and plasmidless strain KM-218 were compared in SDS-PAGE. As shown in Fig. 1, many $\mathrm{pLCR}$-encoded proteins were either absent from strain EV-76 grown at neutral $\mathrm{pH}(7.2-7.0)$ or seen as diffuse zones that were probably being degraded by pla protease (Fig. 1, lanes 8, 9). However, the same proteins appeared as distinct clear protein bands in strain KM-217 independently of $\mathrm{pH}$ (Fig. 1, lanes 1-5) and in strain EV-76 grown at $\mathrm{pH} 4.0-5.0$ (Fig. 1, lanes $6,7)$. Among them some proteins with mol. wts similar to those of Yops and YPPs described previously $[4,5,8,11-14]$ were identified. Confirmation of their identity to each other was determined by dot-ELISA and immunoblotting (data not shown) with rabbit antiYPPs antibody [14]. Moreover, several potentially new pLCR-encoded proteins (nos. 2, 3, 5-12) were found. Interestingly, the data obtained demonstrated that $Y$. pestis was able to synthesise a few proteins (nos. 7-12) only in acidic $\mathrm{pH}$ corresponding to the phagolysosomal environment [19], i.e., pH-dependent acidic proteins. These have not been described previously, but based on mass comparison, proteins 7-12 could be acidic proteins orfs $85,60,61,54,74$ and 73, respectively, described by Perry et al. [22].

Although their functions are unknown at present, these proteins are probably directly involved in blocking of phagocytosis by $Y$. pestis, in preventing the respiratory burst, neutralising acidic hydrolase activity, poisoning macrophages, or promoting escape of bacteria from the phagolysosome into the cell cytoplasm of the macrophage. Nevertheless, these pLCR-encoded products are required for survival of $Y$. pestis within phagolysosomes. The acidic conditions of the phagolysosomal environment make this hypothesis feasible.

The question remained whether the synthesis of Yops (proteins) was regulated by temperature as reported previously $[4-12,13]$ or not. Comparative analysis of whole-cell lysate profiles of strain EV-76 grown at different $\mathrm{pH}$ values at $28^{\circ} \mathrm{C}$ or $37^{\circ} \mathrm{C}$ demonstrated that most proteins were expressed in strain EV-76 independently of cultivation temperature (Fig. 2). However, some of them appeared in strain EV-76 grown at $37^{\circ} \mathrm{C}$ or at lower $\mathrm{pH}$ in larger amounts. Moreover, proteins with the same mol. wt (nos. 2, 4, 5, 10, 12, 40 and 42) were found when strain EV-76 was grown only in acidified Hottinger broth without any supplements (Fig. 3 ). Interestingly, a set of new acidic proteins (nos. 4557) was also found in $Y$. pestis EV-76 cultured in these conditions independently of temperature of cultivation (Fig. 3). Thus, cultivation temperature and, probably, addition of $\mathrm{Mg}^{2+}$ stimulated $Y$. pestis protein synthesis to a lesser extent than acidification of growth media.

A surprising finding in this study was that the acidic conditions promoted synthesis of chromosomally-encoded proteins (Fig. 1) as well as some changes in LPS O-specific polysaccharide chains. Moreover, these chromosomally-encoded proteins were also degraded by pla protease if strain EV-76 was grown in neutral $\mathrm{pH}$ (Fig. 1, lane 9) and could easily be visualised in the same strain grown at acidic $\mathrm{pH}$ (Fig. 1, lanes 6, 7). This explains why these proteins could not be found previously when pLCR-encoded products were studied [4, 5, 7-14]. Furthermore, there was a perfect correlation between $\mathrm{pH}$ of growth medium and differences in $O$-side chains of $Y$. pestis LPS which become shortened within the phagolysosome. Thus, this antigen could not be considered to be of conserved composition and being an endotoxin it may also be involved in the processes of survival, growth and proliferation of $Y$. pestis in the phagolysosome. Combined with the results presented above, these experiments show the significant role of acidification of $\mathrm{Ca}^{2+}$-deficient medium for in-vitro modelling of $Y$. pestis survival during its residence within phagolysosome. These data agree with the observations of Charnetzky and Shuford [1] that the $Y$. pestis life cycles in vivo and in vitro are not completely analogous in the system used and that the results of earlier studies of $Y$. pestis residing within phagolysosomes in high $\mathrm{pH} \mathrm{Ca}{ }^{2+}$-deficient medium in 
vitro should be interpreted with caution. Indeed, the application of acid growth medium provided a closer simulation of the phagolysosomal environment and demonstrated that $Y$. pestis residing within phagolysosomes remains viable, proliferates and produces a set of specific proteins, including some that are $\mathrm{pH}$ dependent.

We thank Dr N. Ye. Teryoshkina for help in preparing the manuscript. We are grateful to Dr M.N. Islyaeva, Dr D. V. Utkin and Mrs Ye. V. Mitina for excellent technical assistance.

\section{References}

1. Charnetzky WT, Shuford WW. Survival and growth of Yersinia pestis within macrophages and an effect of the loss of the 47megadalton plasmid on growth in macrophages. Infect Immun 1985; 47: 234-241.

2. Straley SC, Harmon PA. Growth in mouse peritoneal macrophages of Yersinia pestis lacking established virulence determinants. Infect Immun 1984; 45: 649-654.

3. Straley SC, Harmon PA. Yersinia pestis grows within phagolysosomes in mouse peritoneal macrophages. Infect Immun 1984; 45: 655-659.

4. Perry RD, Fetherston JD. Yersinia pestis - etiologic agent of plague. Clin Microbiol Rev 1997; 10: 35-66.

5. Cornelis GR, Boland A, Boyd AP et al. The virulence plasmid of Yersinia, an antihost genome. Microbiol Mol Biol Rev 1998; 62: $1315-1352$.

6. Bölin I, Portnoy DA, Wolf-Watz H. Expression of temperatureinducible outer membrane proteins of yersiniae. Infect Immun 1985; 48: 234-240.

7. Sample AK, Fowler JM, Brubaker RR. Modulation of the lowcalcium response in Yersinia pestis via plasmid-plasmid interaction. Microb Pathog 1987; 2: 443-453.

8. Straley SC, Brubaker RR. Cytoplasmic and membrane proteins of yersiniae cultivated under conditions simulating mammalian intracellular environment. Proc Natl Acad USA 1981; 78: 1224-1228.

9. Zhahorchak RJ, Brubaker RR. Effect of exogenous nucleotides on $\mathrm{Ca}^{2+}$ dependence and $\mathrm{V}$ antigen synthesis in Yersinia pestis.
Infect Immun 1982; 38: 953-959.

10. Fowler JM, Brubaker RR. Physiological basis of the low calcium response in Yersinia pestis. Infect Immun 1994; 62: 5234-5241.

11. Vidyaeva NA, Kutyrev VV, Protsenko OA, Oleinikov PN, Anisimov PI. [Expression of Yersinia pestis antigens coded by the $\mathrm{Ca}^{2+}$ dependence plasmid]. Mol Gen Mikrobiol Virusol 1990; 6: 17-21.

12. Kutyrev VV. Genetic analysis of virulence determinants in Yersinia pestis. DSc Thesis, Russia State Antiplague Research Institute 'Microbe', Russia. 1992.

13. Sodeinde OA, Sample AK, Brubaker RR, Goguen JD Plasminogen activator/coagulase gene of Yersinia pestis is responsible for degradation of plasmid-encoded outer membrane proteins. Infect Immun 1988; 56: 2749-2752.

14. Feodorova VA, Devdariani ZL. Immunogeneity and structural organisation of some pLCR-encoded proteins of Yersinia pestis. J Med Microbiol 2001; 50: 13-22.

15. Beesley ED, Brubaker RR, Janssen WA, Surgalla MJ. Pesticins. III. Expression of coagulase and mechanism of fibrinolysis. $J$ Bacteriol 1967; 94: 19-26.

16. Feodorova VA, Devdariani ZL. Development, characterisation and diagnostic application of monoclonal antibodies against Yersinia pestis fibrinolysin and coagulase. J Med Microbiol 2000; 49: 261-269.

17. Laemmli UK. Cleavage of structural proteins during the assembly of the head of bacteriophage T4. Nature 1970; 227: $680-685$.

18. Tsai C-M, Frasch CF. A sensitive silver stain for detecting lipopolysaccharides in polyacrylamide gels. Anal Biochem 1982; 119: 115-119.

19. Janeway CA, Travers $F$ (eds) Immunobiology. The immune system in health and disease, 3rd edn. London, Current Biol Ltd. 1997: 8.27-8.28.

20. Andreenko GV (ed) Fibrinoliz: khimiia i fiziologiia protoessa. [Fibrinolysis: chemistry and physiology of the process.] Moskow, Meditsina. 1967.

21. Alkjaersing N, Fletcher AP, Sherry S. The activation of human plasminogen. I. Spontaneous activation in glycerol. II. A kinetic study of activation with trypsin, urokinase, and streptokinase. J Biol Chem 1958; 233: 81-85, 86-90.

22. Perry RD, Straley SC, Fetherston JD, Rose DJ, Gregor J, Blattner FR. DNA sequencing and analysis of the low-Ca ${ }^{2+}$ response plasmid pCD1 of Yersinia pestis KIM5. Infect Immun 1998; 66: 4611-4623. 